\title{
IMPLEMENTASI METODE BACKPROPAGATION JARINGAN SARAF TIRUAN DALAM MEMPREDIKSI POLA PENGUNJUNG TERHADAP TRANSAKSI
}

\author{
Randi Rian Putra \\ Fakultas Sains dan teknologi Jurusan sistem computer Universitas Pembangunan Panca budi \\ J1. Jend. Gatot Subroto, KM 4,5 Medan, Sumatera Utara, indonesia \\ Randirian@dosen.pancabudi.ac.id
}

\begin{abstract}
This study aims to predict the behavior of visitors to transactions so they can predict based on the number of visitors and the number of transactions. To achieve optimal output, this study uses the Backpropagation Method Artificial Neural Network. Case studies conducted at UD. Dilla Tofu And Tempe, The data used is sales report data in April 2017 as training data and sales report data in May 2017 as testing data. Next, the data is analyzed with several network architectural patterns and the best patterns will be selected to be implemented into the matlab program. System results show a correlation between the number of visitors and transactions that occur.
\end{abstract}

Keywords - Predictions, Backpropagation, Number of Visitors, Amount of Transactions

Abstrak - Penelitian ini bertujuan untuk memprediksi prilaku pola pengunjung terhadap transaksi sehingga dapat memprediksi berdasarkan jumlah pengunjung dan jumlah transaksi. Untuk mencapai output yang optimal maka penelitian ini menggunakan Jaringan Syaraf Tiruan Metode Backpropagation. Studi kasus yang dilakukan di UD. Tahu Dan Tempe Dilla, Data yang digunakan adalah data laporan penjualan pada bulan April 2017 sebagai data training dan data laporan penjualan pada bulan Mei 2017 sebagai data testing. Selanjutnya, data dianalisa dengan beberapa pola arsitektur jaringan dan pola yang terbaik akan dipilih untuk di implementasikan ke program matlab. Hasil sistem menunjukan korelasi antara jumlah pengunjung dan transaksi yang terjadi.

Kata Kunci - Prediksi, Backpropagation, Jumlah Pengunjung, Jumlah Transaksi

\section{PENDAHULUAN}

Para pedagang di pasaran yang menjual tahu dan tempe semakin meningkat. Dari peningkatan tersebut, akibatnya persaingan juga semakin meningkat sehingga dibutuhkan strategi penjualan yang baik. Pada umumnya, sistem penjualan melihat dari jumlah pendapatan pada transaksi penjualan perhari yang dapat dijadikan sebagai tolak ukur suatu keberhasilan pedagang tersebut. Transaksi penjualan tersebut sangat dipengaruhi oleh konsumen dan pengunjung.

Jumlah pengunjung dan jumlah transaksi yang dilakukan setiap harinya pasti berbeda-beda. Tetapi, jika jumlah pengunjung banyak belum menentukan jumlah transaksi semakin Prediksi sendiri sebenarnya memperkirakan data yang akan dihasilkan pada masa yang akan datang dengan menggunakan data data yang terjadi sebelumnya.

Oleh karena alasan tersebut, maka penulis akan melakukan riset untuk memproduksi jumlah pengunjung di UD.Tahu Dan Tempe Dilla, di mana jumlah pengunjung tersebut sangat mempengaruhi jumlah transaksi penjualan yang akan terjadi. Jika pengunjung banyak belum menentukan jumlah transaksi semakin besar. Begitu juga sebaliknya, jika pengunjung sedikit belum menentukan jumlah transaksi semakin kecil. Sehingga para pedagang mencari solusi untuk menigkatkan pendapatan penjualan, mulai dari menjual barang barang yang baru sampai menjual dengan harga lelang.

Akibat dari pola transaksi yang terjadi setiap harinya berbeda beda, maka diperlukan sistem yang dapat memprediksi kemungkinan transaksi penjualan yang terjadi dimasa yang akan datang, untuk menyelesaikan permasalahan baik dari segi penjualan maupun dari segi pengunjung sehingga instruksiinstruksi yang di harapkan dapat berjalan dengan semestinya dan dapat meingkatkan kualitas dari suatu perusahaan.

A. Jaringan Saraf Tiruan

Jaringan Saraf Tiruan (JST) saat ini telah berkembang dengan pesat dan telah diimplementasikan dalam berbagai bidang. Salah satu implementasi dalam bidang ekonomi adalah untuk memprediksi kebangkrutan. Prediksi kebangkrutan telah menjadi salah satu topik yang menarik, mengingat keuntungan yang diperoleh apabila dapat melakukan prediksi kebangkrutan (Arizona Z.M.,2013).

\section{B. Karakteristik Jaringan Syaraf Tiruan} Karakteristik dari Jaringan Saraf Tiruan antara lain :

1. Memiliki kemampuan menghasilkan output terhadap pola yang belum pernah Dipelajari.

1. Memiliki kemampuan untuk memproses input yang terdapat kesalahan didalamnya dengan tingkat toleransi tertentu.

3. Mampu beradaptasi dengan perubahan yang terjadi terhadap nilai-nilai input dan output. Bentuk adaptasi ini diwujudkan dalam perubahan nilai bobot.

4. Akurasi prediksi pada umumnya cukup tinggi. 
5. Memerlukan waktu yang relatif lama dalam pembelajaran (Iriansyah B.M.S., 2009)

\section{Backpropagation}

Backpropagation merupakan salah satu dari metode pelatihan pada Jaringan Syaraf Tiruan, dimana ciri dari metode ini adalah meminimalkan error pada output yang dihasilkan oleh jaringan. Backpropagation melatih jaringan untuk mendapatkan keseimbangan antara kemampuan jaringan mengenali pola yang digunakan selama Training serta kemampuan jaringan untuk memberikan respon yang benar terhadap pola masukan yang serupa (tapi tidak sama) dengan pola yang dipakai selama pelatihan ( Dwi S.P., 2016).

\section{Arsitektur Backpropagation}

Setiap unit dari layer input pada jaringan Backpropagation selalu terhubung dengan setiap unit yang berada pada layer tersembunyi, demikian juga setiap unit layer tersembunyi selalu terhubung dengan unit pada layer output.(Agustin M. and Prahasto T., 2012)

Jaringan Backpropagation terdiri dari banyak lapisan (multilayer network) yaitu:

1. Lapisan input (1 buah), yang terdiri dari 1 hingga $n$ unit input.

2. Lapisan tersembunyi (minimal 1 buah), yang terdiri dari 1 hingga $p$ unit tersembunyi.

3. Lapisan output (1 buah), yang terdiri dari 1 hingga m unit output.

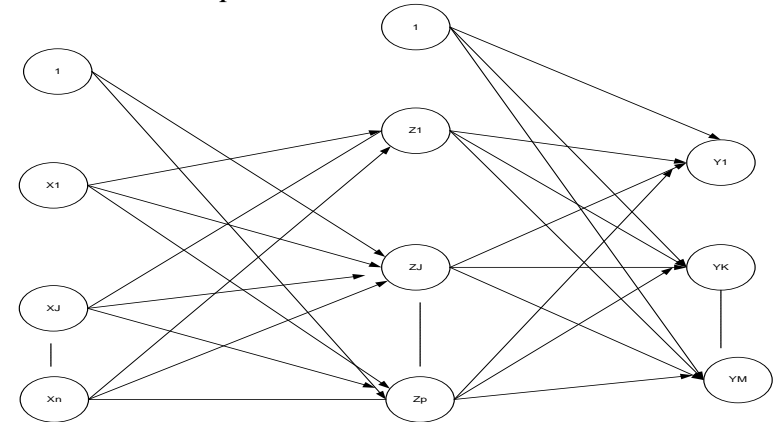

Gambar 1 Arsitektur Propagasi Balik

\section{E. Algoritma Propagasi Balik}

Pengertian Backpropagation adalah penurunan gradien meminimalkan kuadrat error output atau keluaran. Ada tiga tahapan dalam pelatihan jaringan antara lain: forward propagation atau perambatan maju, tahap perambatan balik, dan tahap perubahan bobot dan bias. Jaringan ini mempunyai arsitektur yang terdiri dari input layer, hidden layerdan ouput .

Langkah - langkah dalam metode Backpropagation adalah sebagai berikut:

1. Inisialisasi bobot jaringan secara acak

2. Untuk setiap contoh data, hitungan keluaran berdasarkan bobot jaringan saat tersebut

3. Lakukan proses perhitungan nilai error untuk setiap keluaran dan hidden node (neutron) dalam jaringan. Bobot relasi jaringan dimodifikasi.
4. Ulang langkah ke 2 sehingga mencapai kondisi yang diinginkan Beberapa cara dalam memodifikasi bobot-bobot Jaringan Saraf Tiruan,

\section{PERANCANGAN}

Di dalam melakukan proses penelitian untuk prediksi pola pengunjung terhadap transaksi dirancang sebuah narasi penelitian untuk menyelesaikan permasalahan yang di angkat. Untuk lebih jelas, dapat dilihat dari gambar 4.1 di bawah ini.

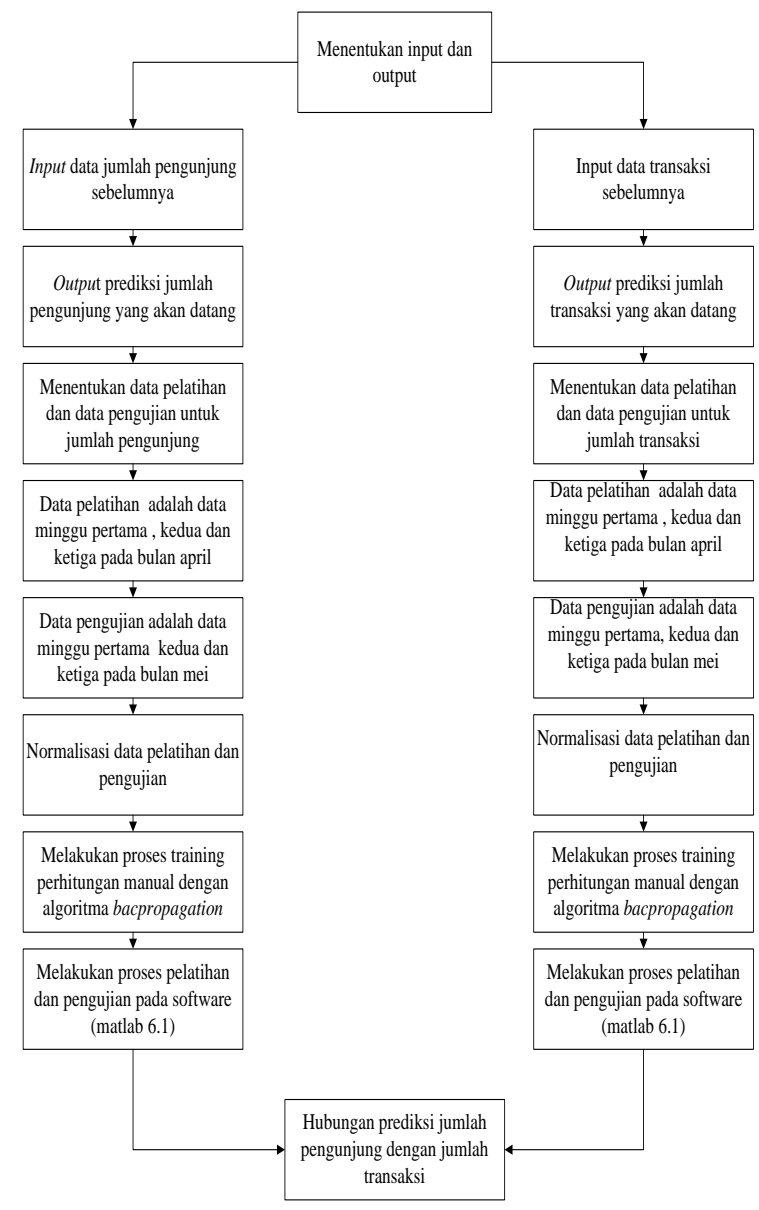

Gambar 2 Prediksi prilaku pola pengunjung

\section{HASIL DAN PEMBAHASAN}

\section{Pengujian Sistem}

Pada tahap pengujian sistem dilakukan training terhadap data sampel ke Jaringan Syaraf Tiruan dengan algoritma backpropagation. Setelah dilakukan training terhadap jaringan tersebut, selanjutnya dilakukan testing dengan menggunakan data testing yang ada, yaitu data pada bulan Mei 2016.

Tabel 1. Input dan Output Jumlah Transaksi dan Pengunjung 


\begin{tabular}{|c|c|c|c|c|c|c|c|}
\hline \multicolumn{4}{|c|}{ Jumlah Pengunjung } & \multicolumn{4}{|c|}{ Jumlah Transaksi } \\
\hline \multicolumn{3}{|l|}{$\mathrm{Xi}$} & \multirow[t]{2}{*}{$\mathrm{T}$} & \multicolumn{3}{|l|}{$\mathrm{Xi}$} & $\mathrm{T}$ \\
\hline $\mathrm{Xl}$ & $\mathrm{X} 2$ & $\mathrm{X} 3$ & & $\mathrm{Xl}$ & $\mathrm{X} 2$ & $\mathrm{X} 3$ & \\
\hline 0,55 & 0,80 & 0,60 & 0,64 & 0.9 & 0.9 & 0.9 & 0.8 \\
\hline 0,30 & 0,90 & 0,10 & 0,10 & 0.508023 & 0.341744548 & 0.407492 & 0.4 \\
\hline 0,10 & 0,20 & 0,90 & 0,47 & 0.1 & 0.1 & 0.1 & 0,1 \\
\hline 0,35 & 0,90 & 0,13 & 0,16 & 0.725788 & 0.797819315 & 0.767101 & 0,6 \\
\hline 0,70 & 0,80 & 0,47 & 0,61 & 0.184814 & 0.139875389 & 0.287622 & 0,1 \\
\hline 0,90 & 0,60 & 0,73 & 0,90 & 0.551576 & 0.573520249 & 0.540391 & 0,4 \\
\hline 0,60 & 0,10 & 0,83 & 0,67 & 0.56533 & 0.536137072 & 0.70456 & 0,6 \\
\hline
\end{tabular}

2. Pengujian Terhadap 5 Model Arsitektur Untuk menguji akurasi pelatihan jaringan tiruan digunakan beberapa model Arsitektur Jaringan Syaraf Tiruan, yaitu dengan menggunakan arsitektur jaringan 3-1-1,3-2-1,3-31, 3-4-1, dan 3-5-1

3. Hasil Pengujian

Dari hasil pengujian dengan 5 arsitektur Jaringan Syaraf Tiruan pada data Training di atas , maka didapatkaan beberapa nilai Error untuk jumlah pengunjung dan jumlah transaksi sehingga dapat dilihat mana nilai error terkecil dan terbesar.

Tabel 2 Nilai Error Pengujian jumlah Pengunjung

\begin{tabular}{|l|l|l|l|l|l|}
\hline \multirow{2}{*}{ N0 } & \multicolumn{5}{l}{ Arsitektur Jaringan Syaraf Tiruan } \\
\cline { 2 - 6 } & $3-1-1$ & $3-2-1$ & $3-3-1$ & $3-4-1$ & $3-5-1$ \\
\hline 1 & 0.0642 & 0.0624 & 0.1322 & 0.1980 & 0.1133 \\
\hline 2 & -0.0026 & -0.0294 & -0.0069 & -0.0236 & -0.0168 \\
\hline 3 & -0.1045 & 0.1607 & 0.1312 & 0.0044 & -0.0804 \\
\hline 4 & -0.4159 & -0.1760 & -0.2008 & -0.1561 & -0.1629 \\
\hline 5 & 0.0342 & -0.0796 & -0.1026 & -0.0763 & 0.0258 \\
\hline 6 & 0.3246 & 0.0456 & 0.0561 & 0.0026 & 0.1434 \\
\hline 7 & 0.0979 & 0.0070 & -0.0089 & -0.0049 & -0.0514 \\
\hline Total Error & -0.0021 & -0.0093 & 0.0003 & -0.0559 & -0.029 \\
\hline Rata-Rata Error & -0.0003 & -0.0013 & 4.2857 & -0.008 & -0.0041 \\
\hline Max Error & 0.3313 & 0.1607 & 0.1322 & 0.1980 & 0.1434 \\
\hline Min Error & -0.0027 & -0.0294 & -0.0069 & 0.0026 & -0.0168 \\
\hline
\end{tabular}

Tabel 3 Nilai Error Pengujian jumlah Transaksi

\begin{tabular}{|l|l|l|l|l|l|}
\hline \multirow{2}{*}{10} & \multicolumn{5}{|l|}{ Arsitektur Jaringan Syaraf Tiruan } \\
\cline { 2 - 6 } & $3-1-1-1$ & $3-2-1$ & $3-3-1$ & $3-4-1$ & $3.5-1$ \\
\hline 1 & 0.1446 & 0.0425 & 0.1564 & -0.0415 & 0.0210 \\
\hline 2 & 0.1065 & -0.0054 & 0.0230 & 0.1389 & 0.1179 \\
\hline 3 & -0.1703 & -0.2112 & 0.0146 & -0.1136 & -0.1152 \\
\hline 4 & 0.0072 & -0.0297 & 0.0552 & -0.1748 & -0.0289 \\
\hline 5 & -0.0614 & -0.0640 & 0.1349 & -0.0046 & -0.1123 \\
\hline 6 & -0.0669 & 0.0968 & -0.1326 & 0.0561 & 0.1567 \\
\hline 7 & 0.0208 & 0.0959 & -0.0773 & -0.0484 & -0.0660 \\
\hline Total Error & -0.0195 & -0.0751 & 0.1742 & -0.1879 & -0.0268 \\
\hline Rata-Rata Error & -0.00279 & -0.01073 & 0.024886 & -0.02684 & -0.00383 \\
\hline Max Error & 0.1446 & 0.0968 & 0.1564 & 0.1389 & 0.1567 \\
\hline Min Error & -0.0614 & -0.0054 & -0.0773 & -0.0046 & -0.0289 \\
\hline
\end{tabular}

Dari tabel di atas terlihat bahwa rata-rata error yang terkecil adalah menggunakan arsitektur jaringan 3-3-1 jadi untuk data testing yang akan digunakan arsitektur jaringan 3-3-1. Untuk jumlah transaksi yang terlihat dari tabel 5.13 di atas nilai error terkecil adalah menggunakan arsitektur jaringan 3-1-1. Jadi untuk data testing yang akan digunakan adalah arsitektur 3-1-1.

a. Hasil Pengujian Data Testing Untuk Jumlah

Pengunjung

Dari hasil Pengujian data training untuk jumlah pengunjung maka arsitektur yang terbaik adalah arsitektur jaringan 3-1-1 maka untuk pengujian data testing ini menggunakan arsitektur jaringan 3-1-1.

Tabel 4. Hasil Data Pengujian Prediksi Jumlah pengunjung

\begin{tabular}{|c|c|}
\hline $\begin{array}{l}\text { Jumlah pengunjung } \\
\text { Aktual }\end{array}$ & $\begin{array}{l}\text { Jumlah pengunjung } \\
\text { Prediksi }\end{array}$ \\
\hline 0.47 & 0.6006 \\
\hline 0.60 & 0.5599 \\
\hline 0.54 & 0.5505 \\
\hline 0.10 & 0.0752 \\
\hline 0.58 & 0.6915 \\
\hline 0.90 & 0.7686 \\
\hline 0.85 & 0.7054 \\
\hline
\end{tabular}

a. Hasil Pengujian Data Testing Untuk Jumlah Transaksi

Dari hasil Pengujian data training untuk jumlah pengunjung maka arsitektur yang terbaik adalah arsitektur jaringan 3-1-1 maka untuk pengujian data testing ini menggunakan arsitektur jaringan 3-1-1. 
Tabel 5. Hasil Data Pengujian Prediksi Jumlah Transaksi

\begin{tabular}{|c|c|}
\hline $\begin{array}{l}\text { Jumlah } \\
\text { Transaksi } \\
\text { Aktual }\end{array}$ & $\begin{array}{l}\text { Jumlah Transaksi } \\
\text { Prediksi }\end{array}$ \\
\hline 0.90 & 0.7598 \\
\hline 0.46 & 0.448 \\
\hline 0.10 & 0.2647 \\
\hline 0.80 & 0.6972 \\
\hline 0.25 & 0.2927 \\
\hline 0.52 & 0.5112 \\
\hline 0.65 & 0.7529 \\
\hline
\end{tabular}

Dari tabel diatas, hasil data terlihat pada Gambar berikut:

b. Hubungan Prediksi Prilaku Pola Pengunjung Terhadap Transaksi

Hubungan prediksi prilaku pola pengunjung terhadap transaksi terlihat pada gambar berikut:

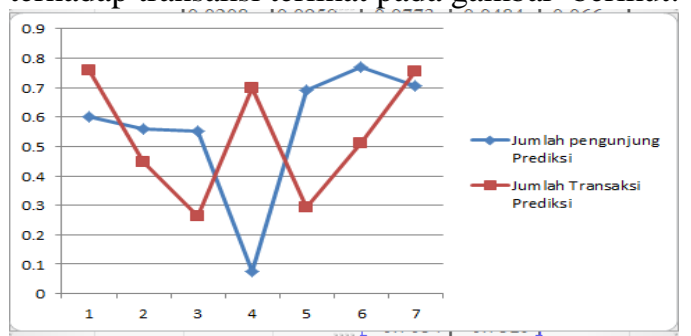

Gambar 9. Grafik Hubungan Prediksi Prilaku Pola Pengunjung Terhadap Transaksi

Gambar diatas menunjukkan bahwa jumlah pengunjung tidak menentukan banyak atau tidaknya jumlah transaksi yang terjadi. Terlihat pada nomor 2 dan 3 yaitu pada hari Selasa Dan Rabu di mana jumlah Pengunjung yang diprediksi hasilnya hampir sama tetapi pada jumlah Transaksi hasil prediksinya berbeda.

\section{KESIMPULAN}

\section{A. Kesimpulan}

Pada grafik dapat diambil kesimpulan sebagai berikut:

1. Untuk Nomor 1 dan no 7, yaitu hari Senin dan Minggu terdapat jumlah transaksi yang tinggi dengan jumlah pengunjung yang hampir sama dan pada no 4 dengan jumlah pengunjung sedikit tetapi transaksi terbanyak ketiga, dihari itu minat beli pengunjung sangat tinggi.
2. Untuk Nomor 2, 3, 5 dan 6, yaitu hari Selasa, Rabu, Jumat dan Sabtu dimana jumlah pengunjung tinggi tetapi jumlah transaksi sedikit. Pada hari-hari itu jumlah pengunjung sangat banyak tetapi minat beli sangat sedikit sehingga perlu dilakukan peningkatan penjualan dengan cara memberi promo seperti diskon pada hari tersebut untuk menarik minat beli pengunjung dalam jumlah yang banyak.

Berdasarkan penelitian implementasi dan pengujian maka dapat diambil kesimpulan secara umum sebagai berikut:

a. Prediksi jumlah transaksi berdasarkan jumlah pengunjung dapat menjawab permasalahan kaitan antara jumlah pengunjung dan jumlah Transaksi pada masa yang akan datang.

b. Tidak hanya pola transaksi dan pengunjung yang terlihat dari hasil pelatihan, Ternyata model juga menggambarkan pola pengunjung yang datang ke UD. Tahu dan Tempe Dilla, Hal ini dapat dijadikan pertimbangan tentang pergantian pegawai dihari tertentu.

\section{DAFTAR PUSTAKA}

[1] Agustin M. and Prahasto T., (2012), Penggunaan Jaringan Syaraf Tiruan Backpropagation Untuk Seleksi Penerimaan Mahasiswa Baru Pada Jurusan Teknik Komputer Di Politeknik Negeri Sriwijaya.

[2] Andrijasa M.F. and Mistianingsih.,( 2010), Penerapan Jaringan Syaraf Tiruan Untuk Memprediksi Jumlah pengangguran di provinsi kalimantan timur dengan menggunakan algoritma pembelajaran bacpropagation.

[3] Arizona Z.M.,( 2013), Jaringan Syaraf Tiruan dengan Algoritma Bacpropagation Untuk penentuan kelulusan sidang skripsi.

[4] Dahriani H.T., (2015), Jaringan Syaraf Tiruan dengan Backpropagation untuk Memprediksi penyakit Asma.

[5] Dwi S.P., (2016), Implementasi Jaringan Syaraf Tiruan bacpropagation sebagai Estimasi laju tingkat pengangguran terbuka pada Provinsi Jawa Timur.

[6] Iriansyah B.M.S., (2009), Prediksi Perilaku Pola Pengunjung Terhadap Transaksi Pada Toko Buku Gramedia Menggunakan Jaringan Syaraf Tiruan Metode Back Propagation .

[7] Sudarsono A., (2016), Jaringan Syaraf Tiruan Untuk Memprediksi Laju Pertumbuhan Penduduk Menggunakan metode Bacpropagation .

[8] Suwardi U., Sukur A., Ricardus A.P., (2012), Komparasi Algoritma Bacpropagation, Nearest, neighbor dan decision tree untuk 
mendeteksi penyakit demam berdarah pada pasien opname. 